\title{
Ship Production Cost Analysis of Conversion From Minajaya 11 Tuna Long Liner Ship to Fish Carrier Ship
}

\author{
Taufik Fajar Nugroho ${ }^{1}$, Raja Oloan Saut Gurning ${ }^{2}$, Eddy Setyo Koenhardono ${ }^{3}$, Irfan Byna Nur Akbar ${ }^{4}$
}

(Received: 28 July 2017 / Revised: 24 June 2019 / Accepted: 02 July 2019)

\begin{abstract}
MV Minajaya Tuna Long Liner Ship number 11 is a fishing vessel and one from 24 Minajaya shipsets owned by PT. Industri Kapal Indonesia (IKI). Minajaya 11 has 512 GT capacity hence, it is prohibited by the government to be operated. Therefore Minajaya 11 will be converted into fish carrier vessel, fish carrier vessel scenario itself is sailing to several fishing grounds locate at WPP 716 in Indonesia and to objectify Minajaya 11 as fish carrier vessel, ship production cost has to be analyzed. The Calculation of ship production cost generally divided into three different types, those are reparation, installation and dismantling, from three different groups there are divided into 4 different task, human resources, material, equipment and energy cost. The total cost from reparation is $\mathbf{R p} \mathbf{8 5 0 . 0 0 0 . 0 0 0}$ with the biggest proportion came from human resources with $49 \%$ proportion and the lowest proportion came from energy price with $2 \%$ proportion. The total cost from installation is Rp. 1.545 .000 .000 with the biggest proportion came from material and shipping cost with $88 \%$ proportion and the lowest proportion came from energy cost with $0 \%$ proportion. The total cost from dismantling is Rp. 25.700 .000 with the biggest proportion came from human resources cost with $77 \%$ proportion and the lowest proportion came from material cost with $0 \%$ proportion. Total conversion production cost needed by Minajaya 11 is Rp. 2.902.000.000 while the conversion activities will be finished in 5 months and 6 days approximately.
\end{abstract}

Keywords_Fish carrier vessel, fishing ground, Reparation, Installation, Dismantling, Human resources, Material and shipping, Equipment cost, Energy cost

\section{INTRODUCTION}

$\mathrm{M}$ inajaya Tuna Long Liner Ship is classified as fishing vessel and particularly designed for catching tuna. All of 31 Minajaya shipsets were owned by PT. Industri Kapal Indonesia (IKI). Latest regulation from Ministry of Marine Affairs and Fisheries No.B.1234/DJTP/P.I410.D3/31/12/2015 implies a prohibition to all fishing vessels above $150 \mathrm{GT}$ to be operated. Hence, Minajaya which has 512 GT can't be operated. Due to the regulation, Minajaya can't be operated for a period of time and needs reparation to restore the function of the ship.

Alternative way can be implied to Minajaya to obtain profit. Minister of Marine Affairs and Fisheries appoint PT. Industri Kapal Indonesia (IKI) to modify Minajaya from fishing vessel into fish carrier vessel. Minajaya as Fish carrier vessel is projected to load the fish from fishing vessels at fishing grounds, this fish carrier vessel will also be projected to help logistics needed by fishing vessels that are currently at fishing grounds.

This scenario will be implied to Minajaya number 11 that will be the object from this thesis. The comprehensiveness from the document, design and

\footnotetext{
Taufik Fajar Nugroho, Departement of Marine Engineering, Institut Teknologi Sepuluh Nopember, Surabaya, 60111, Indonesia. E-mail: taufikfajar@its.ac.id

Raja Oloan Saut Gurning, Departement of Marine Engineering, Institut Teknologi Sepuluh Nopember, Surabaya, 60111, Indonesia. Email: sautg@its.ac.id

Eddy Setyo Koenhardono, Departement of Marine Engineering, Institut Teknologi Sepuluh Nopember, Surabaya, 60111, Indonesia. Email: eddy-koen@its.ac.id

Irfan Byna Nur Akbar, Departement of Marine Engineering, Institut Teknologi Sepuluh Noepmber, Surabaya, 60111, Indonesia. E-mail: Irfan_byna@yahoo.com
}

arrangement from Minajaya number 11 become the reason to choose Minajaya number 11 as the object of this thesis. Currently Minajaya number 11 is located at PT. Industri Kapal Indonesia dock in Makassar, South Sulawesi.

Reparation and systems modification are needed to optimize Minajaya's operational as fish carrier vessel. Reparation, Installation and dismantling cost will be analysed to objectify Minajaya 11 as fish carrier vessel. Therefore, the ship production cost needed to convert Minajaya 11 from fishing vessel into fish carrier vessel will be discussed comprehensively.

\section{METHOD}

\section{A. Definition of Fish Carrier Vessel}

According to Law Number 45 Year 2009, Chapter V Article 34 about fishery business, fishing vessels are defined as vessels who help or perform the process of fish catching and support the operation of fish catching. In general, fishing vessels are divided into the following types; fish carrier, supervisor ship, fishing vessel, and survey ships.

Fish Carrier vessel is a vessel or boats used for carrying and transportation of the fish or fishery products should be equipped with refrigeration or cold store and or refrigerator containing crushed ice with necessary degree of temperature [1].

In accordance with the determination of The Minister of Marine and Fisheries Number 11/MEN/2004, fish carrier vessel specifically works for the activities of carrying fish, including refrigerating, storing, and carrying. Several countries have applied the concept of fish carrier vessel, as well as Norway, that has already had 109 fishing vessels and 4 fish carrier vessels since 1991. This concept was developed as a solution to the 
inefficiency of fishing vessels that catch the fish in fishing ground then go back to the port all at once. The inefficiency was considered as a waste to ship's operational cost.

With the new fish carrier concept developed, the fishing vessel doesn't have to go back to the port. The fish carrier vessels are the ones that carry the fishes back to the port.

\section{B. Calculation of Production Cost}

Production cost is defined as the total cost used for manufacturing the modification of a ship by adding up raw material cost, human resources cost, and any other costs needed as long as the manufacturing process. The ship's required cost is the total cost of material cost and human resources cost involved in production process of shipbuilding construction $[2,10,11]$.

Production cost required to modify Minajaya fishing vessel into fish carrier vessel are divided into three kinds of costs:

1. Reparation Cost covers any costs required to repair all Minajaya ship components from hull to machinery.

2. Installation Cost covers any costs required to install new systems necessary to modify the ship.

3. Dismantling Cost covers any costs required to dismantling process of unnecessary ship components.
Those three kinds of costs can also be broken down into five subcategories, which are:

1. Human resources or Man-hours cost, revenue needed by human resources to do reparation, installation and dismantling activities.

2. Material and Shipping cost, cost needed by material and its shipping cost to do reparation, installation and dismantling activities.

3. Equipment cost, all the cost needed to provide equipment needed for reparation, installation and dismantling activities.

4. Energy cost, all the cost needed to smooth reparation, installation and dismantling activities, for example electricity cost needed during conversion activates held.

5. Tax and vendor profit obtained from $12-14 \%$ of total ship production cost.

Human resources estimated hours are defined using guide that has been produced in order to define the labour costs and evaluated as man-hours, regarding on its component type [3].

Figure 1 shows the diagram for ship production cost or total cost needed to convert Minajaya 11 from tuna long liner fishing vessel to fish carrier vessel.

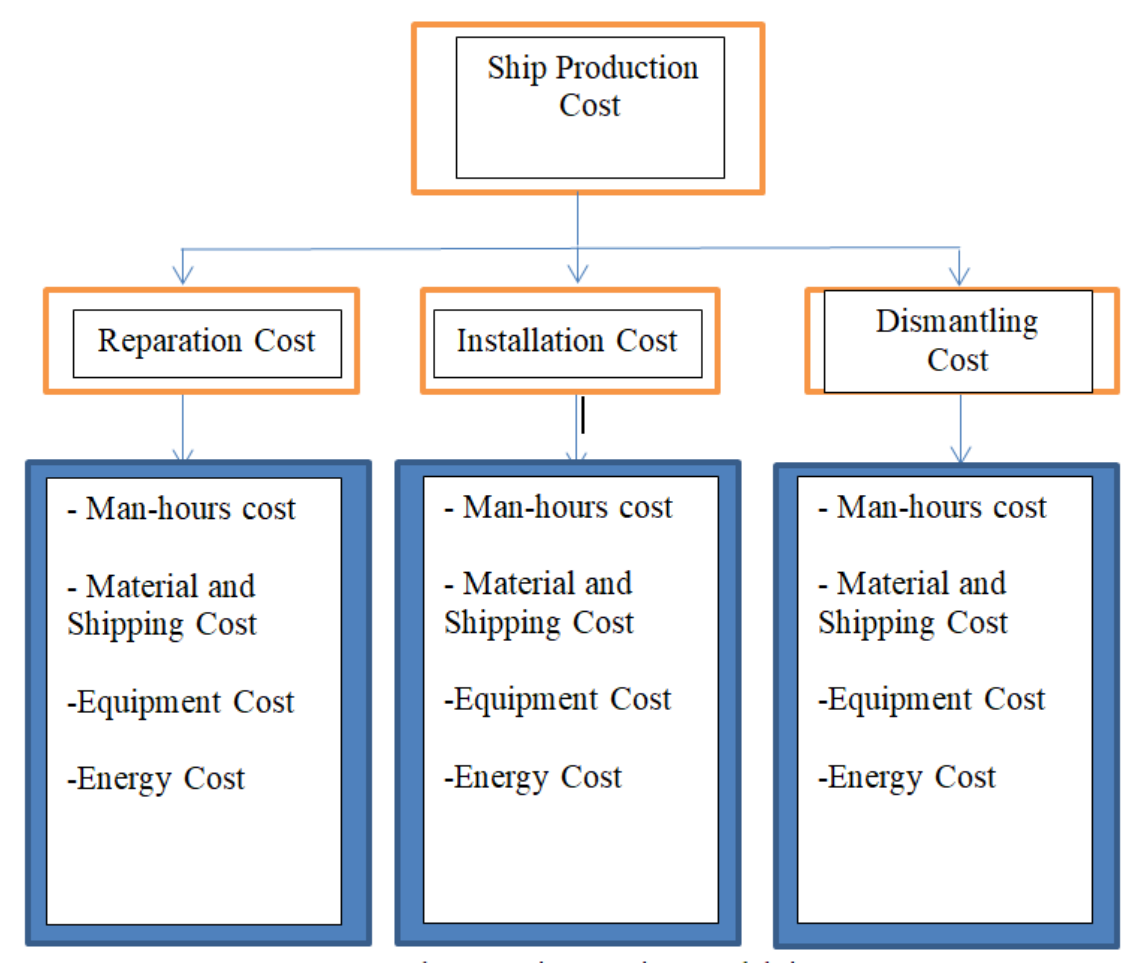

Figure. 1. Ship production conversion cost diagram

\section{Calculation of Shipping Cost}

Shipping can be considered to be an essential transport medium that connects supplier and consumer. The main purpose of shipping is to deliver goods/materials to consumer in good condition [4].

Shipping process is useful to deliver unavailable material in the production place, using standard container ship with material box made of steel/aluminium. International standard for the size of container must be able to carry 20 feet or 40 feet of container.

The calculation of shipping cost to deliver good/material depends on the weight of the material itself, and refers to the following shipping cost equation:

Cost $=$ Wx Pton 
where, Cost is the Shipping Cost (Rp), W is the Item Weight $(\mathrm{kg})$ and $P k g$ is the Shipping cost per ton (Rp).

Shipping cost can be obtained by applying equation 1 , and this shipping cost will be different for each destination.

Table 1 shows the comparison of 20 feet container and 40 feet container; the ship production cost will be based on 20 feet container.

\section{Shipyard Standard for Conversion Activities}

Several regulations such as standard from class define the proper shipyard that can be used for ship conversion activities. Generally, standards needed by the dock to do conversion activates are similar with standards which are needed by repair activates docks [5]. Facilities are based on requirement or recommendation from class to do conversion and reparation activities. Facilities at the dock will affect affinity factor which is needed to optimize conversion and reparation activities. Facilities needed by dock to commit conversion and reparation activities are described at Table 2.

TABLE 1.

STANDARD CONTAINER FOR SHIPPING PURPOSE

\begin{tabular}{ccc} 
& \\
\hline & 20 Feet Container & 40 Feet Container \\
\hline Capacity $\left(\mathrm{m}^{3}\right)$ & 30 & 60 \\
Dimension L X W x H (m) & $5,89 \times 2,32 \times 2,23$ & $12 \times 2,32 \times 2,43$ \\
Door W X H & $2,3 \times 2,14$ & $2,3 \times 2,23$ \\
Maximum load (ton) & 18 & 30 \\
\hline
\end{tabular}

TABLE 2 .

DOCK FACILITIES FOR CONVERSION AND REPARATION ACTIVITIES

\begin{tabular}{llll} 
& & DOCK FACILITIES FOR CONVERSION AND REPARATION ACTIVITIES \\
\hline & \multicolumn{3}{c}{ Dock Facilities needed for conversion and reparation activities } \\
\hline 1. & $\begin{array}{l}\text { Paint Shop } \\
\text { Lifting } \\
\text { Installations }\end{array}$ & 2. & Warehouse \\
5. Technical Services & 4. & Administration office \\
\hline & & \multicolumn{2}{c}{ 6. Health and medical service } \\
\hline 1. & Pipe shop Facilities needed for conversion activities \\
3. & Steelwork hall & 2. & Steel stockyard \\
5. & Block and unit & 6. & Outfitting place \\
& storage area & & \\
\hline
\end{tabular}

\section{E. Ship Production Location Plan}

1) General Consideration

The general overview of ship production location plan is based on Table 2 and other recommendation concerning dock facilities needed for reparation and conversion activities. There are three docks that can be the main options to do the conversion and reparation activities which are:

1. Ship docks located at Makassar, South Sulawesi

2. Ship docks located at Bitung, North Sulawesi

3. Ship docks located at Benoa, Bali.

\section{2) Makassar Ship Dock's Overview}

Minajaya 11 fishing vessel which will be converted is a fishing vessel and currently located at Makassar ship docks. Minajaya 11 condition currently will be need several reparations before being converted to fish carrier ship. The dock facilities are described in the text below:
1. 2x Slipway 6.500 DWT
2. $4 x$ Air bag 6.500 DWT
3. Slipway 1.500 DWT
4. Area graving dock
5. Plater shop

The dock's capability for repairing and converting ship is the main factor that the Minajaya 11 conversion activities will be held at Ship dock at Makassar, North Sulawesi. Therefore, all the cost related to man-hours revenue, material price, equipment price and energy price will be based on the current price that apply on Makassar. Some material prices are obtained from other city than Makassar for example Jakarta, Therefore the material price and the shipping price are the cost needed to transfer material from Jakarta to Makassar. The price will be calculated as material and shipping cost.

Due to Minajaya 11 condition, the ship is currently located at Ship docks on Makassar, South Sulawesi and cannot be delivered to other docks due to reparation requirement. Therefore, Ship docks located at Makassar, South Sulawesi will be chosen as the executor dock to commit conversion and reparation activities on Minajaya 11. All the material and shipping price shall be based upon delivering to Makassar. The placement of reparation, installation and dismantling activities will be located at Makassar ship dock, the dock layout is illustrated.

\section{RESULTS AND DISCUSSION}

\section{A. Man-Hours / Human Resources Cost}

Human resources cost is defined by calculating the man-hours needed for doing the activities then multiplied with Makassar technician's revenue per hour. Total man-hours cost is defined by multiplying manhours for each work with the shipyard human resources cost per hour [6] and the human resources cost per hour will be based on standard that has been given by Inkindo billing rate [7]. Each activity from reparation, installation and dismantling are divided into several groups, which are:

1. Repair activities human resources group will be divided into deck machinery and anchor, machinery I, machinery II, rudder and rudder stock, electrical and electronics, tanks, hull and deck and refrigerating component. 
2. Installation activities human resources group will be divided into bunkering system, safety component, loading unloading system and adsorption refrigerating component

3. Dismantling activities human resources group only covers Fishing Gear.

Each man-hour will be calculated based on the category. Therefore, it will be obtained total man-hours needed for each group (reparation, installation and dismantling) based on standard given by butler, don [8] Human resources cost upon three different groups of conversion activates is Rp. 570.000 .000 with total 10.500 Man-Hours. The percentage distribution of Manhours will be described on Figure 2 and total man-hours needed are described on Table 3.

\section{Human Resources Cost Comparison}

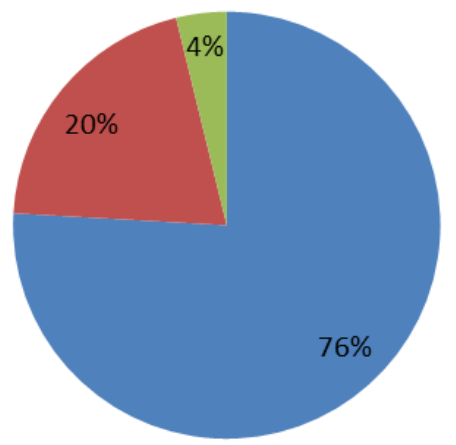

- Reparation

- Installing

Dismantling

Figure. 2. Distribution of human resources cost comparison.

TABLE 3 .

HUMAN RESOURCES COST VALUE

\begin{tabular}{ccc} 
& HUMAN RESOURCES COST VALUE \\
\hline Activities Group & Human Resources Cost & Man-Hours \\
\hline Reparation & 430.000 .000 & 8000 \\
Installing & 115.000 .000 & 2100 \\
Dismantling & 216.000 .000 & 400 \\
Total & 570.000 .000 & 10.500 \\
\hline
\end{tabular}

Figure 2 shows the proportion of Human resources from total cost Rp. 570.000.000. It is shown that reparation takes the most proportion upon two other groups, this is because lack of activities done at installing and dismantling rather than reparation activities.

Table 3 shows the human resources cost on three different conversion activities and man-hours needed each group, it is shown that the longest man-hours goes to reparation group.

\section{B. Material and Shipping Cost}

Material cost and shipping cost are defined according to the material's resource region. For example, there are several materials that planned to be purchased on Jakarta, thus, the total material cost is the sum up from material cost and material shipping cost from Jakarta to Makassar. Total shipping cost distribution is illustrated by Figure 3 . From Figure 3 it can be known that the most shipping cost proportion goes to installation groups (92\%) from total shipping cost from Rp 150.000.000 and total shipping weight from 193 tons. It can be found also from the Figure 3 that dismantling group activities has $0 \%$ proportion from total cost, it is because there is no purchased item for dismantling types. Table 4 shows the shipping cost value from three different conversion group activities with its total weight of shipping in ton. From the table it is known that what cause installing shipping cost so expensive is because the total weight from installing group activates has the weigh test shipping weight with 180 tons.

Shipping cost is only the first part of calculating the total material cost, for determining the total material cost, shipping cost is summed up with material cost needed to purchase the material.

Total material cost proportion is illustrated in Figure 3, while the total values of three different group activities are defined in Table 5 and the proportion of material cost is illustrated on Figure 4. 


\section{Shipping Cost Distribution}

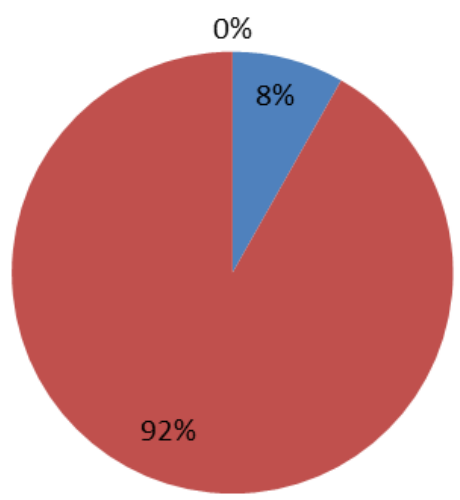

$$
\begin{aligned}
& \text { - Reparation } \\
& \text { Installation } \\
& \text { Dismantling }
\end{aligned}
$$

Figure. 3. Distribution of shipping cost comparison.

TABLE 4.

SHIPPING COST VALUE

\begin{tabular}{ccc}
\hline Group Activities & Shipping Cost (Rp) & Total Weight (ton) \\
\hline Reparation & 12.500 .000 & 12,89 \\
Installation & 140.000 .000 & 180 \\
Dismantling & 0 & 0 \\
Total & 150.000 .000 & 193 \\
\hline
\end{tabular}

\section{Material Cost Distribution}

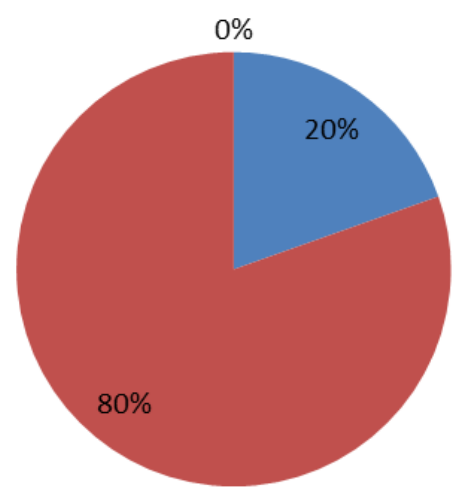

- Reparation

- Installation

Dismantling

Figure. 4. Distribution of material cost comparison.

TABLE 5 .

\begin{tabular}{cc}
\multicolumn{2}{c}{ MATERIAL COST VALUE } \\
\hline Group Activities & Material Cost (Rp) \\
\hline Reparation & 372.000 .000 \\
Installation & 1.530 .000 .000 \\
Dismantling & 0 \\
Total & 1.900 .000 .000 \\
\hline
\end{tabular}

Figure 4 described total material cost distribution after being summed up with shipping cost, from the figure it is obtained that domination from the proportion comes from installation group with $80 \%$ proportion from total cost Rp. 1.900.000.000. The most value from installation group is similar with shipping cost distribution which the shipping cost takes the most proportion at installation groups.

Table 5 shows every cost value from three different group activities (reparation, installation and dismantling) it is obtained the dismantling cost is 0 because there was no material purchased or shipping cost added to the dismantling group activity.

\section{Equipment Cost}

Equipment cost covers all the equipment needed to fulfil the conversion activities according to man-hours activities from three different group activities which are:

1. Equipment cost on reparation group activity is divided into several tasks, those tasks are deck 
machinery and anchor, Machinery I, Machinery II and hull \& deck.

2. Equipment cost on installation group activity is divided into several tasks, those are bunkering system, safety component, loading \& unloading system and adsorption refrigeration system.
3. Equipment cost on dismantling group activity is consist of dismantling fishing gear. List of equipment cost on three different group is illustrated on the Table $6,7,8$.

TABLE 6 .

EQUIPMENT COST VALUE REPARATION GROUP ACTIVITY

\begin{tabular}{cc}
\hline Task Type & $\begin{array}{c}\text { Equipment Cost } \\
(\mathrm{Rp})\end{array}$ \\
\hline Deck Machinery \& Anchor & 2.650 .000 \\
Machinery I & 5.400 .000 \\
Machinery II & 8.000 .000 \\
Rudder \& rudder stock & 495.000 \\
Propeller \& Shaft & 1.400 .000 \\
Electrical and Electronics & 4.000 .000 \\
Tanks & 5.400 .000 \\
Hull \& Deck & 36.800 .000 \\
Refrigerating Component & 6.000 .000 \\
Total & 70.100 .000 \\
\hline
\end{tabular}

TABLE 7.

EQUIPMENT COST VALUE INSTALLATION GROUP ACTIVITY

\begin{tabular}{cc}
\hline Task Type & $\begin{array}{c}\text { Equipment Cost } \\
(\mathrm{Rp})\end{array}$ \\
\hline Bunkering System & 44.000 .000 \\
Safety Component & 3.400 .000 \\
Loading \& Unloading System & 2.000 .000 \\
Adsorption Refrigeration System & 23.000 .000 \\
Total & 72.400 .000 \\
TQUIPMENT COST VALUE DISMANTLING GROUP ACTIVITY \\
\hline Task Type & Equipment Cost (Rp) \\
\hline Dismantling Fishing Gear & 3.200 .000 \\
Total & 3.200 .000 \\
\hline
\end{tabular}

\section{Equipment Cost Distribution}

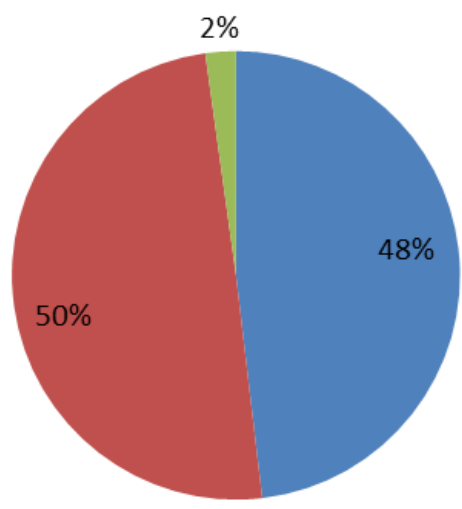

Figure. 5. Distribution of equipment cost comparison.

Table 6,7,8 shows the equipment cost needed for each task at three different group activities, it is known from the table that the less expensive cost for equipment cost occur at dismantling group activity where the activities at dismantling group is not much as the activities occur at reparation and installation do.

Figure 5 shows the proportion of equipment cost from total equipment cost is Rp. 145.000.000, reparation 
almost took the same proportion than installation does, but in contrast, dismantling cost has the less proportion due to less task that occur in dismantling type.

\section{Energy Cost}

The energy cost calculation from three different group activities consist of electricity power, manufacturing operations, welding, machine tools, fiber laser cutting system and transportation needed to transport the material from dock's warehouse to dry dock and all the energy wasted at conversion activities. [9]
Figure 6 shows the bar chart graph to show the cost summary from three different group activities from conversion activities which is reparation group, installing group and dismantling group.

Figure 6 shows that from total energy cost $\mathrm{Rp}$ 22.000.000, reparation takes the most cost value other than two group activities. The energy cost is consisting of electricity power, and the reparation task has more longer man-hours than installing and dismantling group activities.

\section{Energy Cost From 3 Different Group Activities}

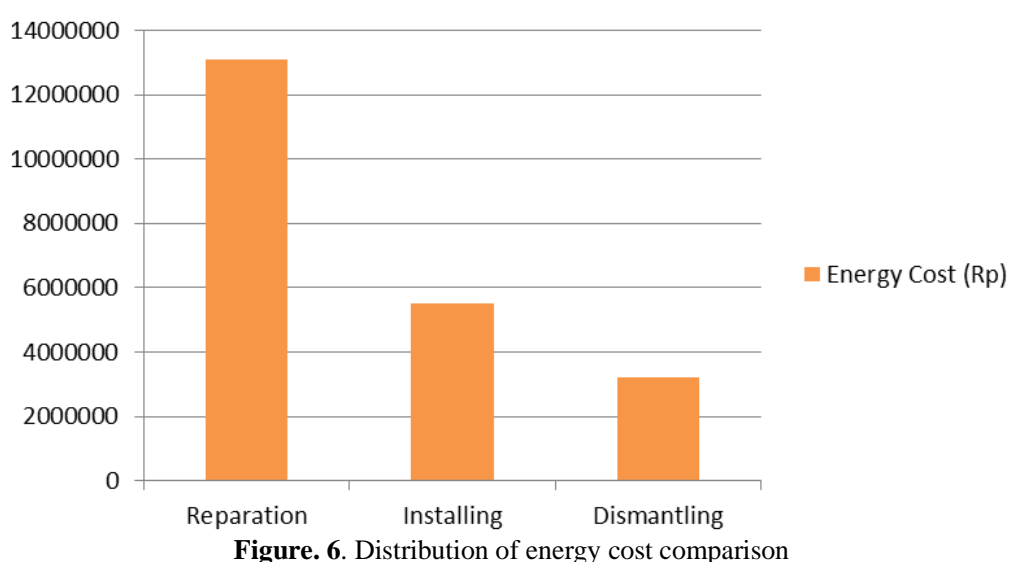

\section{E. Cost Comparsion of Three Different Group Activities}

Total Cost that has to be spent to convert Minajaya 11 fishing vessel to fish carrier vessel is the total sum up from man-hours cost, material and shipping cost, equipment cost, energy cost and in additional summed up with tax and vendor profit, so the total cost is Rp. $2.420 .000 .000+$ Rp. $240.000 .000+$ Rp. $240.000 .000=$ Rp. 2.902.000.000. So the total cost needed to convert Minajaya 11 to fish carrier vessel is Rp. 2.902.000.000 Distribution cost at reparation group activities is shown the biggest proportion with $49 \%$ at human resources, this is because reparation activity is concerning about maintenance main component at Minajaya 11 such as main engine, auxiliary engine, etc.

Therefore, the main concern at reparation group activities is not at purchasing material but to spend much man-hours and human resources to do maintenance and repairing the main component at Minajaya 11 . The lowest proportion with $2 \%$ from total reparation cost Rp. 890.000.000. Table 9 shows the cost value of reparation group activity at four different tasks (human resources, material and shipping, equipment, energy). While Figure 7 shows the pie chart of proportion value from reparation activity.

TABLE 9.

REPAIR COST VALUE AT FOUR DIFFERENT TASK

\begin{tabular}{cc}
\hline Task Type & Cost (Rp) \\
\hline Human Resources & 430.000 .000 \\
Material and Shipping & 370.000 .000 \\
Energy & 13.000 .000 \\
Equipment & 70.000 .000 \\
Total (Approx) & 900.000 .000 \\
\hline
\end{tabular}

Ship production cost distribution on installation is obtained the biggest proportion with $88 \%$ can be found on material and shipping cost, this is because for installing the new component and new system that has been planned on conversion plan need material with high price and high shipping price due to heavy component. For example, the addition item of conveyor from Hamburg that has the expensive material price and high price material as well.
Human resources cost at installation group activity only obtain $7 \%$ from the total installation cost of $\mathrm{Rp}$. 1.700.000.000, this is because on installation process the amount man-hours is not much as reparation activities so the amount of cost for human resources at installation cost will not be high as reparation activities. Energy cost has $0 \%$ proportion because there is a big amount of deviation between energy cost and three other cost. Ship 
production cost distribution on installation is represented

on Table 10 and the pie chart on Figure 8.

\title{
Distribution of Production Cost Repair Type
}

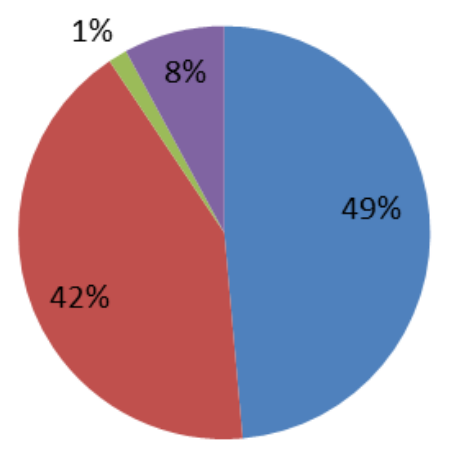

\author{
- HUMAN RESOURCES
}

- MATERIAL

ENERGY

EQUIPMENT

Figure. 7. Distribution of repair cost

Ship production cost distribution on installation is obtained the biggest proportion with $88 \%$ can be found on material and shipping cost, this is because for installing the new component and new system that has been planned on conversion plan need material with high price and high shipping price due to heavy component. For example, the addition item of conveyor from Hamburg that has the expensive material price and high price material as well.
Human resources cost at installation group activity only obtain $7 \%$ from the total installation cost of Rp. 1.700 .000 .000 , this is because on installation process the amount man-hours is not much as reparation activities so the amount of cost for human resources at installation cost will not be high as reparation activities. Energy cost has $0 \%$ proportion because there is a big amount of deviation between energy cost and three other cost. Ship production cost distribution on installation is represented on Table 10 and the pie chart on Figure 8.

TABLE 10.

INSTALLATION COST VALUE AT FOUR DIFFERENT TASK

\begin{tabular}{cc}
\hline INSTALLATION COST VALUE AT FOUR DIFFERENT TASK \\
\hline Task Type & Cost (Rp) \\
\hline Human Resources & 115.000 .000 \\
Material and Shipping & 1.530 .000 .000 \\
Energy & 5.500 .000 \\
Equipment & 70.000 .000 \\
Total (Approx.) & 1.700 .000 .000 \\
\hline
\end{tabular}

\section{Distribution Production Cost Installing Type}

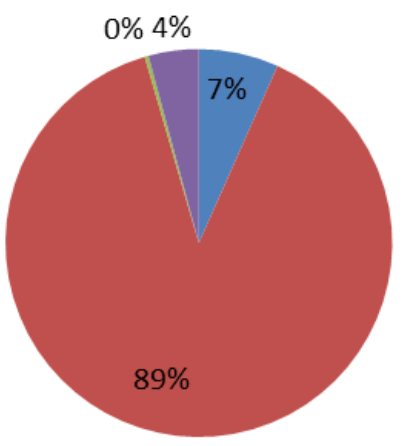


Ship production cost distribution on dismantling is obtained the biggest proportion $77 \%$ can be found on human resources cost, meanwhile the material cost is listed $0 \%$. This is because during the dismantling group activity process there are no cost for buying material or component.
The only matter is the human resources to take out Minajaya 11 component that will no longer needed in the operational scenario as fish carrier vessel. Ship production cost distribution on dismantling group activities is represented on table 11 and Figure 9 for the pie chart.

TABLE 11.

DISMANTLING COST VALUE AT FOUR DIFFERENT TASK

\begin{tabular}{cc}
\multicolumn{2}{c}{ DISMANTLING COST VALUE AT FOUR DIFFERENT TASK } \\
\hline Task Type & Cost (Rp) \\
\hline Human Resources & 21.600 .000 \\
Material and Shipping & 0 \\
Energy & 3.200 .000 \\
Equipment & 3.200 .000 \\
Total (Approx.) & 28.000 .000 \\
\hline
\end{tabular}

\section{Distribusi Production Cost Dismantling Type}

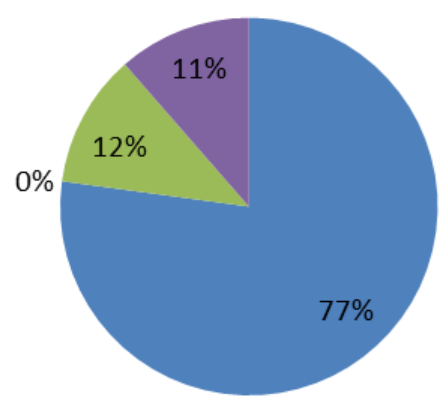

Figure. 9. Distribution of Dismantling Cost.

TABLE 12.

SHIP PRODUCTION COST VALUE AT THREE DIFFERENT GROUP

\begin{tabular}{cc} 
SHIP PRODUCTION COST VALUE AT THREE DIFFERENT GROUP \\
\hline Task Type & Cost (Rp) \\
\hline Reparation & 890.000 .000 \\
Installing & 1.700 .000 .000 \\
Dismantling & 28.000 .000 \\
Total (Approx.) & 2.420 .000 .000 \\
\hline
\end{tabular}

\section{Production Cost Distribution}

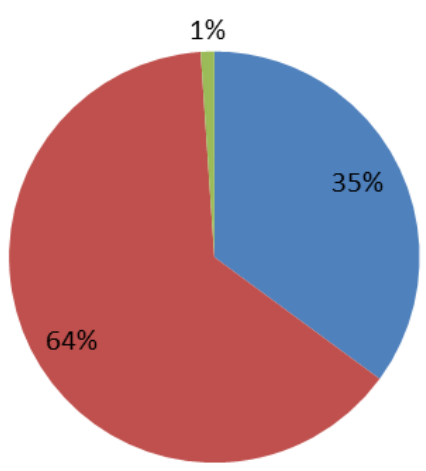

- Reparation

- Installing

Dismantling

Figure. 10. Minajaya 11 Ship Production cost distribution. 


\section{Production Cost Distribution}

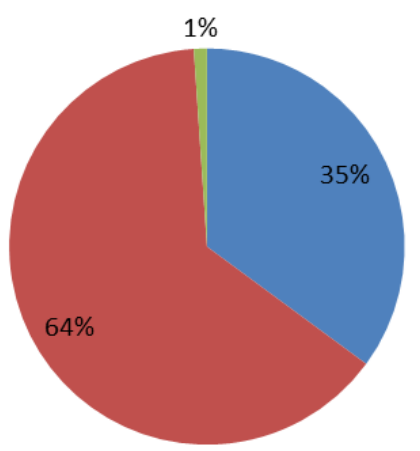

- Reparation
- Installing
Dismantling

Figure. 10. Minajaya 11 Ship Production cost distribution.

So, the total distribution of production cost is obtained with reparation group activities got 64\%, installation group activities $35 \%$ and dismantling group activities got $1 \%$ from total cost of Rp.2.420.000.000. This is because the material at installation process which is more expensive rather than human resources cost at reparation group activity.

Meanwhile dismantling group activity did not spend too much cost due to none material is being brought and also dismantling group did not has shipping cost as well. Ship Production cost distribution upon all group activities is represented at Table 12 for the value and Figure 10 for the pie chart.

\section{CONCLUSION}

Minajaya conversion activities fishing vessel into fish carrier vessel is very useful for both fishing vessel crew and fish carrier crew sides. Fish carrier vessel operational will decrease fishing vessel operational cost due to be able to transaction over logistics and fish hold at the sea with fish carrier vessel, fish carrier vessel will gain benefit too from the transaction.

The Cost analysis defined that, the most value from converting Minajaya 11 from fishing vessel into fish carrier vessel located at Installation group activities, which is the material and shipping cost is the biggest factor why the conversion cost is expensive. In addition, several special reviews is needed to optimize cost of the human resources from reparation group activities and material and shipping cost from installing group activities.

This paper also shows the most proportion of cost that will make the production cost more expensive. In the analysis of distribution of production cost, value of each work type distribution cost are very important to consider the project. In the analysis result, installing type takes $64 \%$ Proportion on production cost over 2 other work types. On the installing type, material is the biggest amongst other 3 other type. Means that installing new systems are much bigger than repairing Minajaya itself.

\section{REFERENCES}

[1] FAO, "Regional Compendium of Fisheris Legislation" vol. 1, pp. 417-418, Rome, 1987.

[2] Watson, D.G.M, "Practical Ship Design", vol. 1, Oxford: Kidlington, pp. 465-466

[3] Butler, D. "Guide to Ship Repair Estimates (In Man-Hours), Reed educational and professional publishing, Linacre house, Jordan Hill, Oxford, 2000, pp.20-80

[4] UNDP, "Shipping and Incoterms" Denmark Patent, Nov. 2008

[5] DNV GL Classification Notes No.8 "Conversion of Ships"

[6] Bertram, V., Maisonneuve J.J., Caprace, J.D., Rigo, P. " Cost Assessment in Ship Production' presented at European Commission's Sixth Framework Programme for Research and Technological Development, pp: 1-2

[7] INKINDO, "Pedoman Standar Minimal 2016 Remuneration Billing Rate and Direct Cost for Consultancy Services, July, 2016

[8] Butler, Don. "Guide to Ship Repair Estimates (In Man-Hours), Butterworth-Heinemann. Oxford: Jordan Hill

[9] Harish, R., Sunil, S.K. "Energy Consumption and Conservation in Shipbuilding", International Journal of Innovative Research \& Development, vol. 4 Issue 7, 2015, pp: 26-31

[10] Bong H.S., Hills W., Caldwell J.B. "Methods of Incorporating Design-for-Production Considerations into Concept Design Investigations" Journal of Ship Production, Vol.6 No.2, pp: 69$80,1990$.

[11] Hekkenberg, R.G., "A Building Cost Estimation Method for Inland Ships." Presented at the European inland waterway navigation conference. Budapest, Hungary, 2014. 